\title{
Klasifikasi Penentuan Manfaat Tanaman Obat Herbal Berbasis Rule Based Reasoning
}

\author{
Yulia Darnita*, Rozali Toyib \\ Program Studi Teknik Informatika Fakultas Teknik universitas Muhammadiyah Bengkulu \\ Jln. Bali, Bengkulu 38119, Indonesia \\ *e-mail: yuliadarnita@umb.ac.id
}

(received: 13 Oktober 2020, revised: 2 Desember 2020, accepted: 19 Desember 2020)

\begin{abstract}
Abstrak
Permasalahan yang dihadapi masyarakat dengan keterbatasan biaya dan terbatasnya stok obat-obatan ditambah dengan krisis finansial dengan sendiri masyarakat harus bisa memanfaatkan tanamantanaman yang ada disekitar lingkungannya, walaupun sebenarnya tanaman obat herbal ini bukanlah sesuatu yang baru melainkan sudah ada sejak dulu dari jaman nenek moyang bangsa ini, mengingat masyarakat sudah maju maka mereka lebih menyukai hal-hal berbau instan dan mudah diadapat serta tidak perlu proses pembautan. Kondisi Covid 19 yang mewabah secara global ditengah keterbatasan obat-obat kimia yang biasa dikonsumsi maka dibutuh alternative pengobatan yang lain dengan obatobat herbal dan kurangnya informasi tentang tanaman obat herbal untuk penyembuhan penyakit, sehingga masyarakat belum mengetahui secara detail keterangan penyakit, proses pembuatan obat, sampai jenis penyakit. Untuk mengatasi masalah tersebut dapat dibangun suatu aplikasi untuk mengklasifikasikan manfaat tanaman obat herbal yang dapat digunakan dalam kehidupan sehari-hari dan sebagai media dan pengenalan tanaman obat dengan menggunakan Rule Based Reasoning dengan Algoritma Depth First Search dalam menemukan solusi yang terbaik dari beberapa solusi yang sama. Hasil pengujian : Klasifikasi penentuan manfaat tanaman obat herbal dari 31 jenis tanaman herbal yang terdiri dari bunga, buah-buahan dan rempa maka dapat 9 kelompok besar dan penggunaan algoritma ini hanya membutuhkan memori yang kecil.
\end{abstract}

Kata Kunci: herbal, obat, tanaman, algoritma depth first search

\begin{abstract}
The problems faced by the community with limited costs and limited stock of medicines coupled with the financial crisis by themselves must be able to take advantage of existing plants around their environment, even though in fact these herbal medicinal plants are not something new but have been around since ancient times. this nation, considering that society is already advanced, they prefer things that smell of instant and easy to obtain and do not need a stitching process. The condition of Covid 19 which is endemic globally amidst the limitations of chemical drugs that are commonly consumed, other alternative treatments are needed with herbal medicines and a lack of information about herbal medicinal plants to cure disease, so that people do not know in detail the information about the disease, the process of making medicine, until the type of disease. To overcome this problem, an application can be built to clarify the benefits of herbal medicinal plants that can be used in everyday life and as a medium and introduction to medicinal plants by using Rule Based Reasoning with the depth first search algorithm in finding the best solution from some of the same solutions. Test results: The classification of the benefits of herbal medicinal plants from 31 types of herbal plants consisting of flowers, fruits and palm leaves can be 9 large groups and the use of this algorithm only requires a small memory.
\end{abstract}

Keywords: herbs, medicines, plants, depth first search algorithm

\section{Pendahuluan}

Keaneka ragaman tumbuhan yang tumbuh di Indonesia beraneka ragam dengan dukung iklim tropis sangat mendukung tumbuh kembang dengan baik, sebagian dari tumbuhtumbuhan tersebut merupakan tumbuhan yang dapat dimanfaatkan untuk mengobati berbagai 
penyakit, tumbuhan tersebut biasa disebut sebagai tanaman obat, Ada beberapa tanaman obat yang dikenal memiliki efek samping yang rendah dibandingkan obat kimia, sehingga dewasa ini banyak orang yang menggunakan tanaman obat untuk mengobati penyakit, serta mengurangi penggunaan obat kimia, dengan kondisi ini memungkin Indonesia bisa memanfaatkan tanaman obat ini untuk meredah dan mengobati penderita covid 19 walaupun tidak bisa di pastikan kesembuhan dengan tanaman obat herbal tetapi bisa digunakan untuk meredahkan efek dari penyakit ini, tanaman obat herbal ini sangat membantu banyak orang tetapi belum banyak tahu fungsi dari masing-masing tanaman dikarenakan kurangnya informasi tentang tanaman itu sendiri sehingga masyarakat belum mengetahui secara detail keterangan penyakit, proses pembuatan obat, sampai jenis penyakit, untuk mengatasi masalah tersebut dapat dibangun suatu aplikasi untuk mengklafikasikan manfaat tanaman obat herbal yang dapat digunakan dalam kehidupan sehari-hari dan sebagai media dan pengenalan tanaman obat dengan menggunakan Rule Based Reasoning dengan Algoritma depth first search ini akan bersifat complete apabila graph atau tree memiliki sifat finite state space namun apabila infinite state space lebih memudahkan untuk menghasilkan kelompok yang sistem pakar menganalisa atau mendiagnosa gejala-gejala yang dengan melakukan penelusuran kaidah secara mendalam dari simpul akar bergerak menurun ke tingkat dalam yang berurutan sehingga setiap pencariannya ditemukannya tujuan yang diinginkan.

Pada penelitian sebelumnya metode Implementasi Metode Klasifikasi Nä̈ve Bayes digunakan Dalam memprediksi besarnya penggunaan listrik rumah tangga, Penerapan metode naïve bayes diharapkan mampu untuk memprediksi besarnya penggunaan listrik tiap rumah tangga agar lebih mudah mengatur penggunaan listrik [1]. Algoritma klasifikasi data mining yang paling akurat untuk prediksi mahasiswa non aktif, Algoritma yang digunakan adalah logistic regression, decision tree, naïve bayes dan neural network. Data yang digunakan sebanyak 3861 mahasiswa program studi Teknik Informatika, Sistem Informasi dan Desain Komunikasi Visual Universitas Dian Nuswantoro[2].

Penelitian ini bertujuan untuk mengklasfikasi tanaman obat herbal menggunakan Rule Based Reasoning dengan Algoritma depth first search pencarian berdasarkan manfaat dari masing-masing tanaman obat melalu proses kaidah pengetahuan sehingga menghasil alternative-alternatif yang bisa digunakan dalam penentuan tanaman obat herbal yang mana cocok untuk pengobatan penyakit.

\section{Tinjauan Literatur}

\section{Klasifikasi}

Klasifikasi nasabah Bank BRI ini bertujuan untuk memudahkan pihak Bank dalam membuat keputusan dalam hal perpanjangan kredit. Dengan adanya klasifikasi nasabah dalam suatu Bank, jika terjadi masalah dengan kasus yang sama pihak Bank tinggal melihat aturanaturan (rule) yang telah terbentuk dari pohon keputusan yang dihasilkanmenggunakan algoritma C4.5 diharapkan proses penggalian informasi lebih cepat dan optimal dengan kapasitas data yang lebih besar, sehingga kesalahan yang ditimbulkan dalam pengambilan keputusan lebih diminimalkan, Aplikasi untuk mengklasifikasi teks bahasa Indonesia secara terpandu (supervised), dengan menerapkan metode naive bayes dalam klasifikasi berita memiliki akurasi yang baik terbukti pada data uji yang bersumber dari situs web menghasilkan nilai akurasi dengan persentase yang tinggi yaitu lebih dari $87 \%$ untuk data latih yang besar (100 artikel) [3]-[4].

\section{Tanaman Obat}

Kekayaan tanaman obat dan obat tradisional merupakan sebuah anugerah yang dimiliki oleh rakyat Indonesia yang belum tercatat dalam sebuah gudang data (datawarehouse) terpusat. Ketiadaan gudang data tersebut menyebabkan minimnya informasi tanaman obat yang dikenal oleh masyarakat dan memungkinkan berulangnya hasil dari penelitian terhadap tanaman obat dengan judul struktur data datawarehouse tanaman obat indonesia dan hasil penelitian obat tradisional[5], Tanaman obat atau dikenal biofarmaka merupakan tanaman yang memiliki khasiat atau kegunaan sebagai tanaman obat terutama bagi keluarga masyarakat Desa Depok Kecamatan Bawang Kabupaten Banjarnegara dengan judul Pemanfaatan Tanaman Obat (Biofarmaka) Sebagai Produk Unggulan Masyarakat Desa 
Depok Banjarnegara, Akhir-akhir ini minuman herbal yang diseduh dari beberapa campuran daun, bunga, biji, akar dan kulit kayu semakin berkembang dan terkenal. Di negara Indonesia sendiri, tanaman herbal juga telah lama digunakan selama bertahun-tahun untuk mengobati berbagai masalah kesahatan dari penelitian dengan judul Black Cincau (Mesona palustris B1.), Pandanus Leaves (Pandanus amaryllifolius) and Cinnamon (Cinnamomum burmannii) Potential as Basic Ingredients of Functional Herbal Drink : A Review [6]-[7]. Tanaman obat keluarga (TOGA) merupakan tanaman yang memiliki banyak khasiat terutama dalam bidang kesehatandengan memanfaatkan tanaman TOGA dapat meningkatkan derajat kesehatan secara mandiri dengan memanfaatkan Tanaman yang bersifat obat, serta memberi pengetahuan kepada seluruh siswa akan pentingnya Toga bagi kesehatan dan memberi pemahaman tentang cara penanaman dan perawatan TOGA yang baik serta membiasakan para siswa dan juga guru untuk menanam tumbuhan terutama TOGA di lingkungan sekolah [8].

\section{Herbal}

Sejarah dikenalnya tanaman herbal di Indonesia, jenis-jenis tanaman herbal, dan fungsi-fungsi olahan tanaman herbal. Proyek ini terletak di kota Solo. Solo merupakan salah satu kota di Jawa Tengah yang masih kental dengan adat istiadatnya dan terdapat keraton yang merupakan cerita awal dari di kenalnya adat jamu tradisional penelitian dengan judul Museum Tanaman Herbal Indonesia di Solo, Kanker payudara adalah penyakit dengan kasus kematian tertinggi kedua setelah penyakit kardiovaskular. Kemoterapi yang merupakan pilihan utama terapi kanker hingga saat ini terbukti menyebabkan beberapa efek samping berbahaya, oleh karena itu, ada kebutuhan mendesak untuk mengembangkan terapi berbasis herbal yang efektif untuk membunuh sel kanker dan meminimalkan efek samping penelitian tentang Mengungkap Potensi Metabolit Sekunder Tanaman Herbal Indonesia untuk Menghentikan Metastasis Kanker Payudara: Pendekatan in-silico [9]-[10]. Tanaman herbal adalah tumbuhan yang telah diidentifikasi dan diketahui berdasarkan pengamatan manusia memiliki senyawa yang bermanfaat untuk mencegah, menyembuhkan penyakit, melakukan fungsi biologis tertentu, hingga mencegah serangan serangga dan jamur penelitian dengan judul Tanaman Herbal Sebagai Tanaman Hias Dan Tanaman Obat[11].

\section{Rule Based Reasoning}

Kerusakan kamera bisa terjadi karena human error, umur kamera. Tanpa pengetahuan yang baik dapat mengakibatkan kamera yang terbilang cukup mahal ini semakin rusak dan tidak dapat digunakan lagi. Minimnya pengetahuan yang dimiliki oleh masyarakat dapat menyebabkan penangan yang salah terhadap pemeliharan/ perawatan kamera DSLR dan hal ini akan berdampak fatal maka digunakanlah metode Case Based Reasoning dalam mengidentifikasi kerusakan kamera dengan cara menganalisis masukkan gejala dan menghasilkan jenis kerusakan pada kamera pengguna, Pemikiran yang terbentuk akibat pengaruh lingkungan dapat memicu anoreksia nervosa diantaranya berupa iklan dimedia massa sehingga masyarakat sangat terpengaruh terutama pada kalangan remaja. Minimnya pengetahuan dan kepedulian terhadap keseimbangan gizi pada tubuh menyebabkan munculnya gangguan Anoreksia Nervosa dengan menggunakan Metode Case Based Reasoning dapat memberikan kemudahan dalam melakukan diagnosa serta memberikan hasil diagnosa yang lebih akurat berdasarkan kejadian terdahulu dan dapat direvisi kembali dalam memecahkan permasalahan yang baru [12]-[13]. Tuberculosis atau yang dikenal dengan TB, adalah suatu penyakit yang disebabkan oleh sebuah virus yang bernama Mycobacterium tuberculosis. Penyakit ini termasuk mematikan karena menyerang oragan paru-paru, di Indonesia sendiri, pada tahun 2012, data dari Kementrian Kesehatan Indonesia menyebutkan bahwa 1 orang meninggal setiap 8 menit karena penyakit TB ini. Hal ini jelas menunjukan betapa bahayanya jenis penyakit ini digunakan sistem pakar untuk mendeteksi metode Case-Based Reasoning (CBR). Data yang digunakan adalah data rekam medis pasien pengidap penyakit TB dengan kasus yang baru atau pasien yang baru mengalami penyakit TB sebanyak satu kali, Penalaran berbasis kasus (Case-Based Reasoning) untuk melakukan diagnosa penyakit berdasarkan gejala-gejala yang ada. Proses diagnosa dilakukan dengan cara memasukkan kasus baru (target case) yang berisi gejala-gejala penyakit yang akan didiagnosa, kemudian dilakukan proses similaritas antara kasus baru dengan kasus-kasus (source case) yang sudah tersimpan di dalam basis data (case-based) sistem[14]-[15]. 


\section{Algoritma Depth First Search}

Algoritma Depth First Search dan Breadth First Search adalah algoritma pencarian buta yang digunakan dalam kecerdasan buatan. Algoritma ini berfungsi untuk menemukan tujuan pada suatu kasus dimana tidak ada informasi tambahan yang dimiliki untuk membantu melakukan pencarian digunakan pada aplikasi Rat Race dan Web Peta pada penelitian Evaluasi dan Usaha Optimalisasi Algoritma Depth First Search dan Breadth First Search dengan Penerapan pada Aplikasi Rat Race dan Web Peta[16]. Suatu graf dapat didefinisikan sebagai suatu himpunan vertexvertex (titik-titik) dengan beberapa di antaranya dihubungkan oleh edge (garis). Jarak dari vertex u dapat didefinisikan sebagai panjang path (lintasan) terpendek dari vertex $u$ ke vertex lain dalam G. Eksentrisitas dari vertex $\mathrm{u}$ adalah jarak maksimum dari vertex $u$ ke vertex lain dalam $G$. Dalam makalah ini akan diselidiki algoritma untuk menentukan eksentrisitas suatu tree menggunakan depth first search penelitian dengan judul Pendekatan Algoritma Untuk Mencari Eksentrisitas Suatu Tree dengan Depth First Search[17].

\section{Smartphone}

Pemanfaatan kemampuan smart phone untuk keperluan di beberapa bidang pun dikembangkan dengan aplikasi-aplikasi yang mampu mendukung dalam penggunaannya diantaranya adalah untuk media pembelajaran edukatif mobile phone sebagai media pembelajaran dalam mempelajari pengertian ilmu hadis yang disertai dengan hadist pilihan dan latihan soal, Smartphone dikatakan sebagai salah satu jenis media baru karena dapat mengakses informasi dengan cepat melalui fasilitas internetnya. Selain itu, manusia dapat berkomunikasi jarak jauh dengan menggunakan smartphone yang memiliki fasilitas beragam tidak hanya terbatas pada telepon, SMS tetapi smartphonesmartphone yang berkembang saat ini menawarkan fitur video call yang memberikan suatu transformasi dalam kegiatan komunikasi yang bisa digunakan mahasiswa Fispol Unsrat lebih cenderung menggunakan smartphone untuk menunjang aktivitas perkuliahan mereka [18]-[19]. Android merupakan sebuah sistem operasi yang bersifat Open Source yaitu memberikan kebebasan bagi developer untuk mengembangkan sebuah aplikasi, dengan kelebihan dari sistem operasi android, akan banyak membantu pengguna smartphone berbasis android untuk dapat menikmati beragam aplikasi, salah satu aplikasi itu adalah Aplikasi Kumpulan Doa Berbasis Android[20].

\section{Metode Penelitian}

\subsection{Metode Pengembangan Sistem}

Metode Rapid Aplication Development (RAD) diperuntukan untuk jangka pendek sesuai dengan aplikasi yang dikembangkan, langkah-langkah sebagai berikut:

1. Fase Perencanaan Syarat-Syarat

Pada fase ini dilakukan analisis kebutuhan apa saja yang dibutuhkan dengan melakukan proses analisis dari sistem yang dibuat, tujuan aplikasi atau sistem serta untuk mengidetifikasi syarat-syarat informasi yang ditimbulkan dari tujuan-tujuan tersebut sperti kebutuhan atas data-data yang dibutuhkan.

2. Fase Perancangan

Berdasarkan analisi dilakukan perancangan yang sesuai dengan kebutuhan yang mencakup Pada proses dan perancangan antar muka dari aplikasi Perancangan proses yang digambarkan dengan digambarkan oleh flowchart.

3. Fase Konstruksi

Pada tahapan ini di lakukan pengkodean terhadap rancangan-rancangan yang telah didefinisikan ke dalam suatu bahasa pemograman untuk memastikan semua tools yang digunakan berfungsi dan mencegah adanya bug.

4. Fase Pelaksanaan

Pada tahapan ini dilakukan pengimplementasian aplikasi, pengujian aplikasi dan analisa hasil pengujian terhadap aplikasi yang juga bertujuan untuk mengetahui tingkat keberhasilan dari aplikasi dalam mencapai hasil yang diinginkan. 


\subsection{Flowchart Aplikasi}

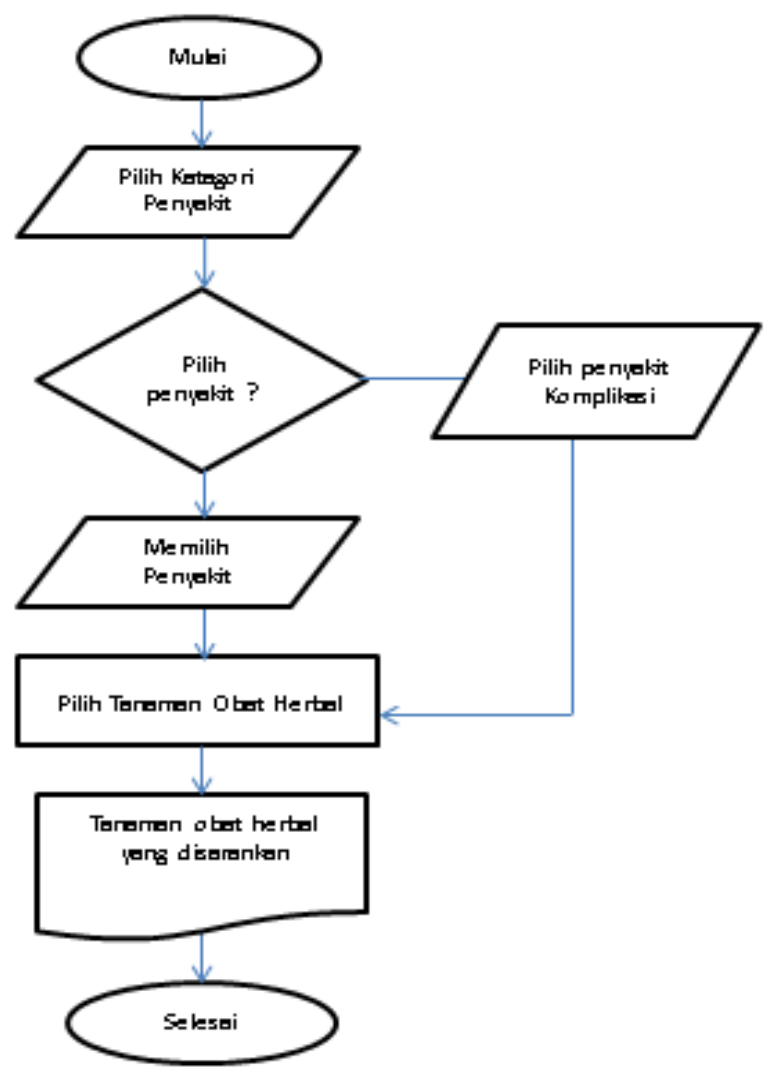

Gambar 1. Flowchart Aplikasi

\subsection{Analisis Manual}

Adapun hasil penerapan Algoritma depth first search untuk Rule Based Reasoning (RBR) tanaman obat berbasis android adalah sebagai berikut:

1. Terdapat 3 tanaman herbal tersebut adalah sebagai berikut:

a. Tanaman herbal berbunga meliputi melati, kecombrang, turi, kembang sepatu, mawar, matahari, lavender, anggrek, tulip, begonia.

b. Tanaman herbal berbuah meliputi alpukat, anggur, apel, asam, belimbing, bengkuang, blueberry, cermai, coklat, delima.

c. Tanaman herbal rempah-rempah meliputi jahe, cengkeh, ketumbar, lengkuas, pala, kunyit, kayu manis, kencur, jintan hitam, daun salam.

2. Untuk memberikan informasi tentang jenis tanaman herbal yang dapat digunakan sebagai obat berbasis Smartphone dengan menggunakan Rule Based Reasoning (RBR)

3. Dapat dijadikan informasi obat herbal berdasarkan jenis penyakit yang lebih mudah, cepat, dan efisien

Melihat dan mengamati beberapa fenomena yang ada, pada penelitian ini memfokuskan pada jenis herba yang sesuai dengan beberapa hal antara lain:

a. Pemodelan penentuan jenis racikan herba yang tepat berdasarkan jenisnya

b. Tidak dapat dipastikan herba mana bermanfaat untuk menyembuhkan penyakit

c. Perlu diperhatikan berkenaan dengan sindrom penderita berbeda beda sehingga dalam menentukan jenis konsumsi herba yang tepat bagi penderita harus dilakukan diagnosa yang tepat dan sesuai dengan kondisinya. 
d. Bisa juga dikaitkan dengan kebutuhan herba yang akan diproduksi mengingat diranah fabrikasi akan berbeda pertimbangan dengan manfaat dan jenisnya

Teknik pelacakan knowledge base yang digunakan adalah depth first search yaitu sistem pakar menganalisa atau mendiagnosa gejala-gejala yang dengan melakukan penelusuran kaidah secara mendalam dari simpul akar bergerak menurun ke tingkat dalam yang berurutan.

Dalam basis pengetahuan terdapat 2 pendekatan, dalam pembuatan sistem pakar ini penulis menggunakan penalaran berbasis aturan (Rule Based Reasoning). Pada penalaran berbasis aturan ini dipresentasikan dengan menggunkan IF-THEN. Bentuk ini digunakan apabila dimiliki sejumlah pengetahuan pakar pada suatu permasalahan tertentu dan si pakar dapat menyelesaikan masalah tersebut secara berurutan.

Tabel 1. Tabel Pengelompokan Berdasarkan Jenis

\begin{tabular}{lll}
\hline No & \multicolumn{1}{c}{ Nama Tanaman Herbal } & \multicolumn{1}{c}{ Jenisnya } \\
\hline 1 & Bunga Melati & Bunga \\
2 & Bunga Kecombrang & Bunga \\
3 & Bunga Turi & Bunga \\
4 & Bunga Hibiscus (Kembang Sepatu) & Bunga \\
5 & Bunga Mawar & Bunga \\
6 & Bunga Matahari & Bunga \\
8 & Bunga Lavender & Bunga \\
9 & Bunga Anggrek & Bunga \\
10 & Bunga Tulip & Bunga \\
11 & Bunga Begonia & Bunga \\
12 & Alpukat & Buah \\
13 & Anggur & Buah \\
14 & Apel & Buah \\
15 & Asam & Buah \\
16 & Belimbing & Buah \\
17 & Bengkuang & Buah \\
18 & Blueberry & Buah \\
19 & Cermai & Buah \\
20 & Coklat & Buah \\
21 & Delima & Buah \\
22 & Jahe & Rempah \\
23 & Cengkeh & Rempah \\
24 & Ketumbar & Rempah \\
25 & Laos/Lengkuas & Rempah \\
26 & Pala & Rempah \\
27 & Kunyit & Rempah \\
28 & Kayu Manis & Rempah \\
29 & Kencur & Rempah \\
30 & Jintan Hitam & Rempah \\
31 & Daun Salam & Rempah \\
\hline
\end{tabular}


Tabel 2. Tanaman Obat Herbal

\begin{tabular}{lll}
\hline No & Kode & \multicolumn{1}{c}{ Keterangan } \\
\hline 1 & T01 & Bunga Melati \\
2 & T02 & Bunga Kecombrang \\
3 & T03 & Bunga Turi \\
4 & T04 & Bunga Hibiscus (Kembang Sepatu) \\
5 & T05 & Bunga Mawar \\
6 & T06 & Bunga Matahari \\
8 & T08 & Bunga Lavender \\
9 & T09 & Bunga Anggrek \\
10 & T10 & Bunga Tulip \\
11 & T11 & Bunga Begonia \\
12 & T12 & Alpukat \\
13 & T13 & Anggur \\
14 & T14 & Apel \\
15 & T15 & Asam \\
16 & T16 & Belimbing \\
17 & T17 & Bengkuang \\
18 & T18 & Blueberry \\
19 & T19 & Cermai \\
20 & T20 & Coklat \\
21 & T21 & Delima \\
22 & T22 & Jahe \\
23 & T23 & Cengkeh \\
24 & T24 & Ketumbar \\
25 & T25 & Laos/Lengkuas \\
26 & T26 & Pala \\
27 & T27 & Kunyit \\
28 & T28 & Kayu Manis \\
29 & T29 & Kencur \\
30 & T30 & Jintan Hitam \\
31 & T31 & Daun Salam \\
\hline & &
\end{tabular}

Pangkalan kaidah ini dibuat untuk menterjemahkan tabel-tabel kaidah produksi sebagai alat bantu untuk mengetahui kegunaan tanaman berkhasiat obat. Basis pengetahuan tanaman berkhasiat obat adalah sebagai berikut:

R1 : IF T14

AND T

AND T01

AND T04

AND T12

AND T13

THEN MENURUNKAN GULA DARAH

R2 : IF T28

AND T01

AND T04

AND T12

AND T14

AND T15

AND T16

AND T20

THEN MENURUNKAN KELOSTROL

R3 : IF T19 
AND T05

AND T11

AND T13

AND T14

AND T15

AND T16

THEN MELANCARKAN PENCERNAAN

R4 : IF T25

AND T10

AND T12

AND T13

AND T14

AND T19

AND T20

AND T21

AND T25

THEN KANKER

R5 : IF T09

AND T03

THEN Demam

R6 : IF T17

AND T01

AND T02

THEN MERAWAT KULIT

R7 : IF T30

AND T03

AND T08

AND T10

AND T22

AND T23

AND T24

AND T26

AND T29

THEN BAKTERI/VIRUS

R8 : IF T24

AND T01

AND T03

AND T05

AND T13

AND T14

AND T15

AND T16

AND T30

THEN DIARE

R9 : IF T27

AND T03

AND T08

AND T10

AND T19

AND T22

AND T23

AND T29

AND T30

THEN PERNAPASAN

R10 : IF T04 
AND T10

THEN ANTI OKSIDAN

R811: IF T09

AND T01

AND T02

AND T03

AND T08

THEN SARIAWAN

Tabel 3. Basis Pengetahuan

\begin{tabular}{|c|c|c|c|c|c|c|c|c|c|c|c|}
\hline & $\mathrm{P} 01$ & $\mathrm{P} 02$ & $\mathrm{P} 03$ & P04 & $\mathrm{P} 05$ & P06 & P07 & P08 & P09 & P10 & P11 \\
\hline T01 & $\begin{array}{l}\mathrm{Y} \\
\end{array}$ & $\mathrm{Y}$ & $\mathrm{T}$ & $\mathrm{T}$ & $\mathrm{T}$ & $\mathrm{Y}$ & $\mathrm{T}$ & $\mathrm{Y}$ & $\mathrm{T}$ & $\mathrm{Y}$ & $\mathrm{Y}$ \\
\hline T02 & $\mathrm{T}$ & $\mathrm{T}$ & $\mathrm{T}$ & $\mathrm{T}$ & $\mathrm{T}$ & $Y$ & $\mathrm{~T}$ & $\mathrm{~T}$ & $\mathrm{~T}$ & $\mathrm{~T}$ & $\mathrm{Y}$ \\
\hline T03 & $\mathrm{T}$ & $\mathrm{T}$ & $\mathrm{T}$ & $\mathrm{T}$ & $Y$ & $\mathrm{~T}$ & Y & $Y$ & $\mathrm{Y}$ & $\mathrm{T}$ & $\mathrm{Y}$ \\
\hline T04 & Y & $Y$ & $\mathrm{~T}$ & $\mathrm{~T}$ & $\mathrm{~T}$ & $\mathrm{~T}$ & $\mathrm{~T}$ & $\mathrm{~T}$ & $\mathrm{~T}$ & $Y$ & $\mathrm{~T}$ \\
\hline T05 & $\mathrm{T}$ & $\mathrm{T}$ & Y & $\mathrm{T}$ & $\mathrm{T}$ & $\mathrm{T}$ & $\mathrm{T}$ & $Y$ & $\mathrm{~T}$ & $\mathrm{~T}$ & $\mathrm{~T}$ \\
\hline T06 & $\mathrm{T}$ & $\mathrm{T}$ & $\mathrm{T}$ & $\mathrm{T}$ & $\mathrm{T}$ & $\mathrm{T}$ & $\mathrm{T}$ & $\mathrm{T}$ & $\mathrm{T}$ & $\mathrm{T}$ & $\mathrm{T}$ \\
\hline T08 & $\mathrm{T}$ & $\mathrm{T}$ & $\mathrm{T}$ & $\mathrm{T}$ & $\mathrm{T}$ & $\mathrm{T}$ & Y & $\mathrm{T}$ & Y & $\mathrm{T}$ & $\mathrm{Y}$ \\
\hline T09 & $\mathrm{T}$ & $\mathrm{T}$ & $\mathrm{T}$ & $\mathrm{T}$ & $Y$ & $\mathrm{~T}$ & $\mathrm{~T}$ & $\mathrm{~T}$ & $\mathrm{~T}$ & $\mathrm{~T}$ & $\mathrm{Y}$ \\
\hline $\mathrm{T} 10$ & $\mathrm{~T}$ & $\mathrm{~T}$ & $\mathrm{~T}$ & $\mathrm{Y}$ & $\mathrm{T}$ & $\mathrm{T}$ & Y & $\mathrm{T}$ & Y & $\mathrm{T}$ & $\mathrm{T}$ \\
\hline $\mathrm{T} 11$ & $\mathrm{~T}$ & $\mathrm{~T}$ & Y & $\mathrm{T}$ & $\mathrm{T}$ & $\mathrm{T}$ & $\mathrm{T}$ & $\mathrm{T}$ & $\mathrm{T}$ & $\mathrm{T}$ & $\mathrm{T}$ \\
\hline $\mathrm{T} 12$ & Y & $\mathrm{Y}$ & $\mathrm{T}$ & $\mathrm{Y}$ & $\mathrm{T}$ & $\mathrm{T}$ & $\mathrm{T}$ & $\mathrm{T}$ & $\mathrm{T}$ & $\mathrm{T}$ & $\mathrm{T}$ \\
\hline $\mathrm{T} 13$ & Y & $\mathrm{T}$ & Y & $\mathrm{Y}$ & $\mathrm{T}$ & $\mathrm{T}$ & $\mathrm{T}$ & $Y$ & $\mathrm{~T}$ & $\mathrm{~T}$ & $\mathrm{~T}$ \\
\hline $\mathrm{T} 14$ & Y & $\mathrm{Y}$ & Y & $\mathrm{Y}$ & $\mathrm{T}$ & $\mathrm{T}$ & $\mathrm{T}$ & $Y$ & $\mathrm{~T}$ & $\mathrm{~T}$ & $\mathrm{~T}$ \\
\hline $\mathrm{T} 15$ & $\mathrm{~T}$ & $\mathrm{Y}$ & Y & $\mathrm{T}$ & $\mathrm{T}$ & $\mathrm{T}$ & $\mathrm{T}$ & $Y$ & $\mathrm{~T}$ & $\mathrm{~T}$ & $\mathrm{~T}$ \\
\hline $\mathrm{T} 16$ & $\mathrm{~T}$ & $\mathrm{Y}$ & $\mathrm{T}$ & $\mathrm{T}$ & $\mathrm{T}$ & $\mathrm{T}$ & $\mathrm{T}$ & $Y$ & $\mathrm{~T}$ & $\mathrm{~T}$ & $\mathrm{~T}$ \\
\hline $\mathrm{T} 17$ & $\mathrm{~T}$ & $\mathrm{~T}$ & $\mathrm{~T}$ & $\mathrm{~T}$ & $\mathrm{~T}$ & $\mathrm{Y}$ & $\mathrm{T}$ & $\mathrm{T}$ & $\mathrm{T}$ & $\mathrm{T}$ & $\mathrm{T}$ \\
\hline $\mathrm{T} 18$ & $\mathrm{~T}$ & $\mathrm{~T}$ & $\mathrm{~T}$ & $\mathrm{~T}$ & $\mathrm{~T}$ & $\mathrm{~T}$ & $\mathrm{~T}$ & $\mathrm{~T}$ & $\mathrm{~T}$ & $\mathrm{~T}$ & $\mathrm{~T}$ \\
\hline T19 & $\mathrm{T}$ & $\mathrm{T}$ & Y & $\mathrm{T}$ & $\mathrm{T}$ & $\mathrm{T}$ & $\mathrm{T}$ & $\mathrm{T}$ & Y & $\mathrm{T}$ & $\mathrm{T}$ \\
\hline $\mathrm{T} 20$ & $\mathrm{~T}$ & $\mathrm{Y}$ & $\mathrm{T}$ & $\mathrm{Y}$ & $\mathrm{T}$ & $\mathrm{T}$ & $\mathrm{T}$ & $\mathrm{T}$ & $\mathrm{T}$ & $\mathrm{T}$ & $\mathrm{T}$ \\
\hline $\mathrm{T} 21$ & $\mathrm{~T}$ & $\mathrm{~T}$ & $\mathrm{~T}$ & $\mathrm{Y}$ & $\mathrm{T}$ & $\mathrm{T}$ & $\mathrm{T}$ & $\mathrm{T}$ & $\mathrm{T}$ & $\mathrm{T}$ & $\mathrm{T}$ \\
\hline $\mathrm{T} 22$ & $\mathrm{~T}$ & $\mathrm{~T}$ & $\mathrm{~T}$ & $\mathrm{~T}$ & $\mathrm{~T}$ & $\mathrm{~T}$ & Y & $\mathrm{T}$ & $\mathrm{Y}$ & $\mathrm{T}$ & $\mathrm{T}$ \\
\hline $\mathrm{T} 23$ & $\mathrm{~T}$ & $\mathrm{~T}$ & $\mathrm{~T}$ & $\mathrm{~T}$ & $\mathrm{~T}$ & $\mathrm{~T}$ & Y & $\mathrm{T}$ & Y & $\mathrm{T}$ & $\mathrm{T}$ \\
\hline $\mathrm{T} 24$ & $\mathrm{~T}$ & $\mathrm{~T}$ & $\mathrm{~T}$ & $\mathrm{~T}$ & $\mathrm{~T}$ & $\mathrm{~T}$ & Y & $Y$ & $\mathrm{~T}$ & $\mathrm{~T}$ & $\mathrm{~T}$ \\
\hline $\mathrm{T} 25$ & $\mathrm{~T}$ & $\mathrm{~T}$ & $\mathrm{~T}$ & $\mathrm{Y}$ & $\mathrm{T}$ & $\mathrm{T}$ & $\mathrm{T}$ & $\mathrm{T}$ & $\mathrm{T}$ & $\mathrm{T}$ & $\mathrm{T}$ \\
\hline T26 & $\mathrm{T}$ & $\mathrm{T}$ & $\mathrm{T}$ & $\mathrm{T}$ & $\mathrm{T}$ & $\mathrm{T}$ & Y & $\mathrm{T}$ & $\mathrm{Y}$ & $\mathrm{T}$ & $\mathrm{T}$ \\
\hline $\mathrm{T} 27$ & $\mathrm{~T}$ & $\mathrm{~T}$ & $\mathrm{~T}$ & $\mathrm{~T}$ & $\mathrm{~T}$ & $\mathrm{~T}$ & $\mathrm{~T}$ & $\mathrm{~T}$ & $\mathrm{~T}$ & $\mathrm{~T}$ & $\mathrm{~T}$ \\
\hline T28 & $\mathrm{T}$ & $\mathrm{Y}$ & $\mathrm{T}$ & $\mathrm{T}$ & $\mathrm{T}$ & $\mathrm{T}$ & $\mathrm{T}$ & $\mathrm{T}$ & $\mathrm{T}$ & $\mathrm{T}$ & $\mathrm{T}$ \\
\hline T29 & $\mathrm{T}$ & $\mathrm{T}$ & $\mathrm{T}$ & $\mathrm{T}$ & $\mathrm{T}$ & $\mathrm{T}$ & Y & $\mathrm{T}$ & $\mathrm{Y}$ & $\mathrm{T}$ & $\mathrm{T}$ \\
\hline T30 & $\mathrm{T}$ & $\mathrm{T}$ & $\mathrm{T}$ & $\mathrm{T}$ & $\mathrm{T}$ & $\mathrm{T}$ & Y & $\mathrm{T}$ & $\mathrm{Y}$ & $\mathrm{T}$ & $\mathrm{T}$ \\
\hline T31 & $\mathrm{T}$ & $\mathrm{T}$ & $\mathrm{T}$ & $\mathrm{T}$ & $\mathrm{T}$ & $\mathrm{T}$ & $\mathrm{T}$ & $Y$ & $\mathrm{~T}$ & $\mathrm{~T}$ & $\mathrm{~T}$ \\
\hline
\end{tabular}

Dalam sistem pakar ini dipilih metode dengan cara Algoritma depth first search yaitu sistem pakar menganalisa atau mendiagnosa gejala-gejala yang dengan melakukan penelusuran kaidah secara mendalam dari simpul akar bergerak menurun ke tingkat dalam yang berurutan

Keterangan :

P01 : MENURUNKAN GULA DARAH

P02: MENURUNKAN KELOSTROL

P03: MELANCARKAN PENCERNAAN

P04: KANKER

P05: DEMAM

P06: MERAWAT KULIT

P07: BAKTERI/VIRUS

P08: DIARE

P09: PERNAPASAN

P10: ANTI OKSIDAN

http://sistemasi.ftik.unisi.ac.id 


\section{P11: SARIAWAN}

\section{Hasil dan Pembahasan}

\subsection{Hasil}

\section{Menu Utama}

Pada tampilan menu utama terdapat 3 button yaitu tanaman bunga, tanaman buah, dan tanaman rempah. Dimana setiap button memiliki fungsi yang berbeda-beda, adapun tampilan menu utama.

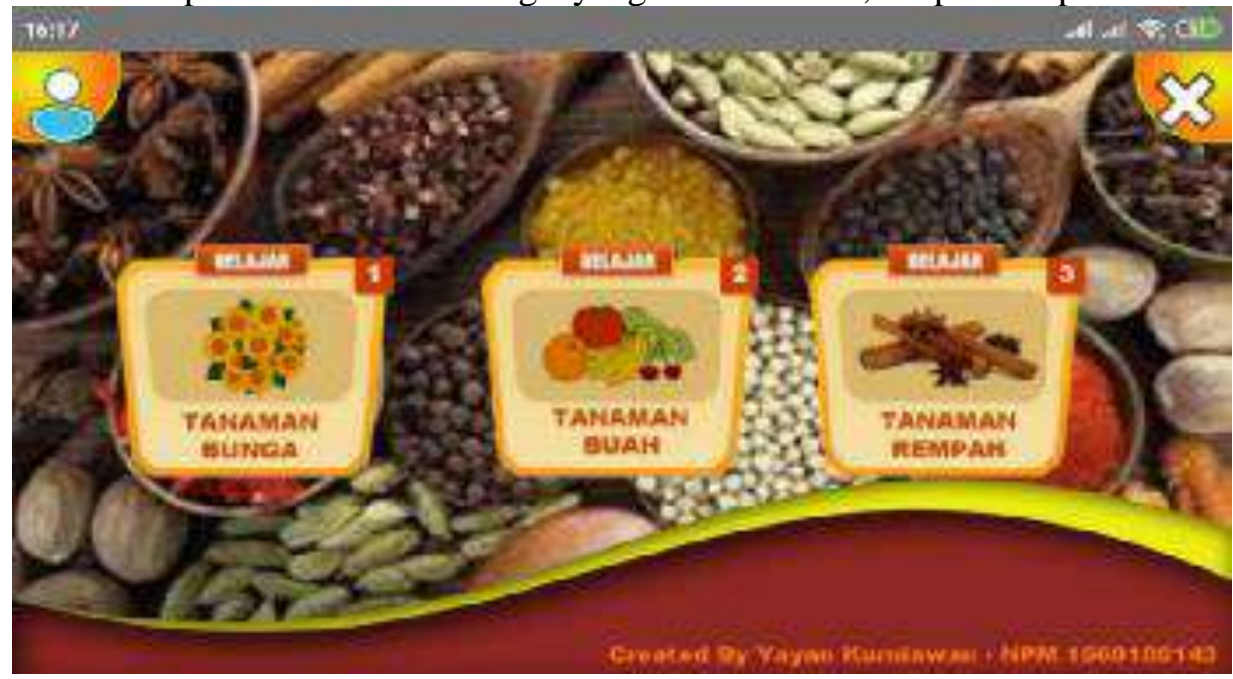

\section{Gambar 2. Menu Utama}

2. Menu Obat Herbal dari Bunga

Pada tampilan menu obat bunga, memberikan informasi tanaman obat bunga baik informasi gambar dan tulisan. Adapun tampilan menu obat bunga.

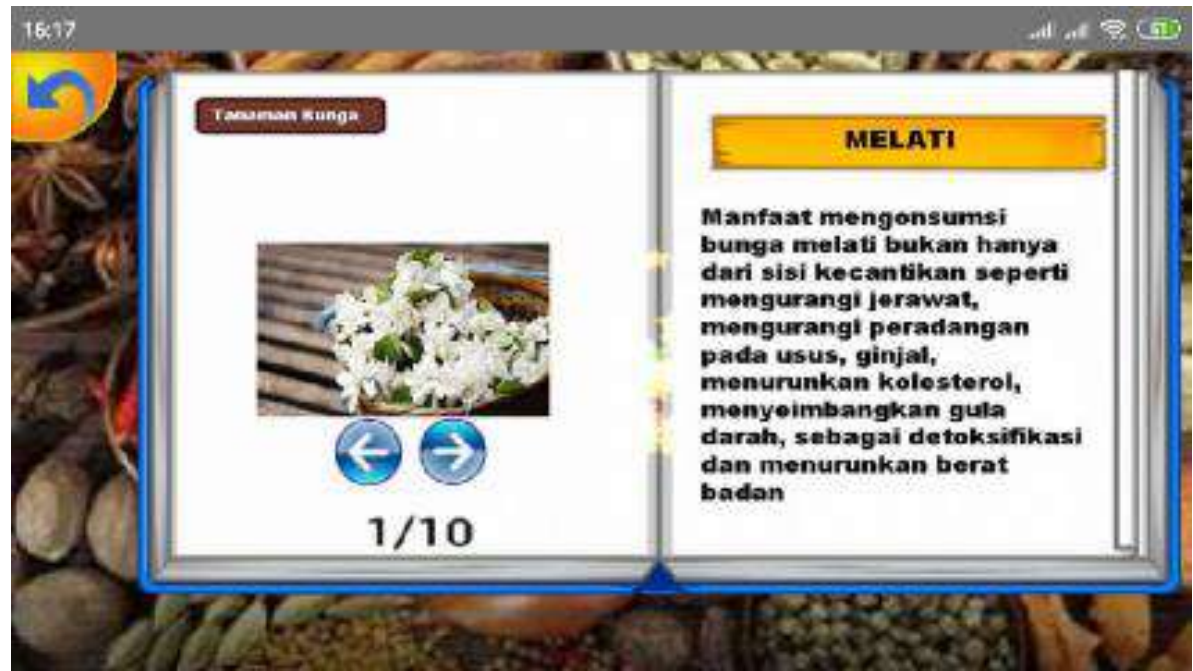

Gambar 3. Menu Obat dari Bunga

3. Menu Obat Herbal dari Buah

Pada tampilan menu obat buah, memberikan informasi tanaman obat buah baik informasi gambar dan tulisan 


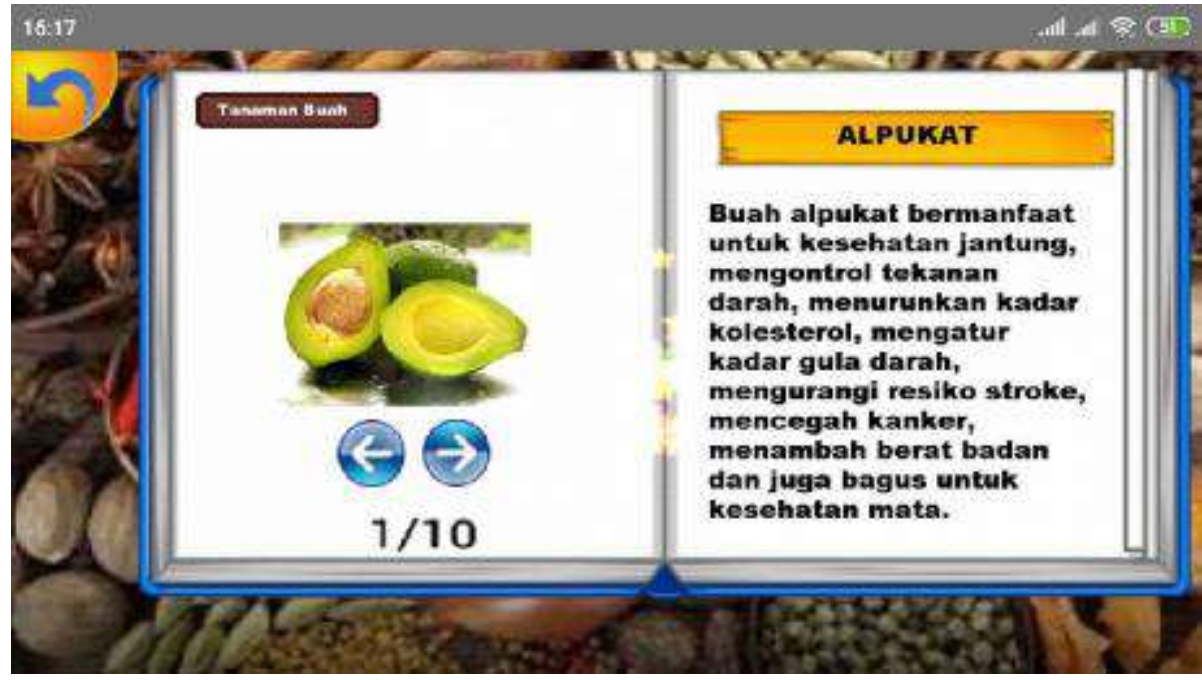

Gambar 4. Obat dari Buah

4. Menu Obat dari Rempah

Pada tampilan menu obat rempah, memberikan informasi tanaman obat rempah baik informasi gambar dan tulisan.

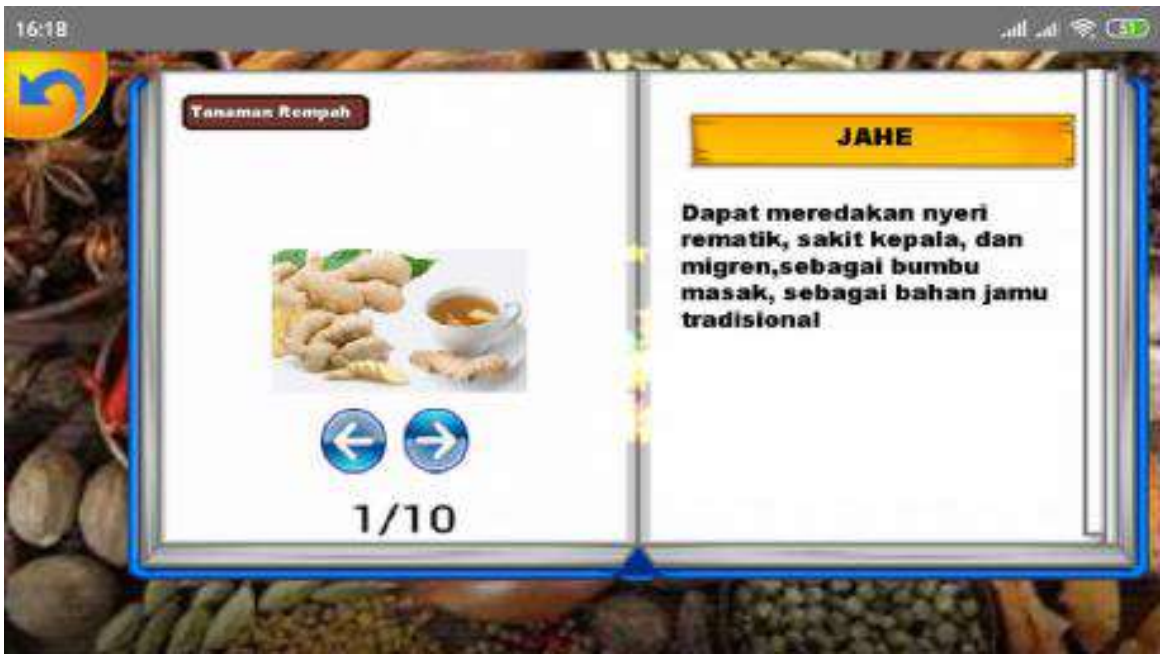

5. Menu Keluar

Gambar 5. Menu Obat Dari Rempah

Tampilan menu keluar merupakan konfirmasi keluar dari aplikasi, adapun tampilan menu keluar

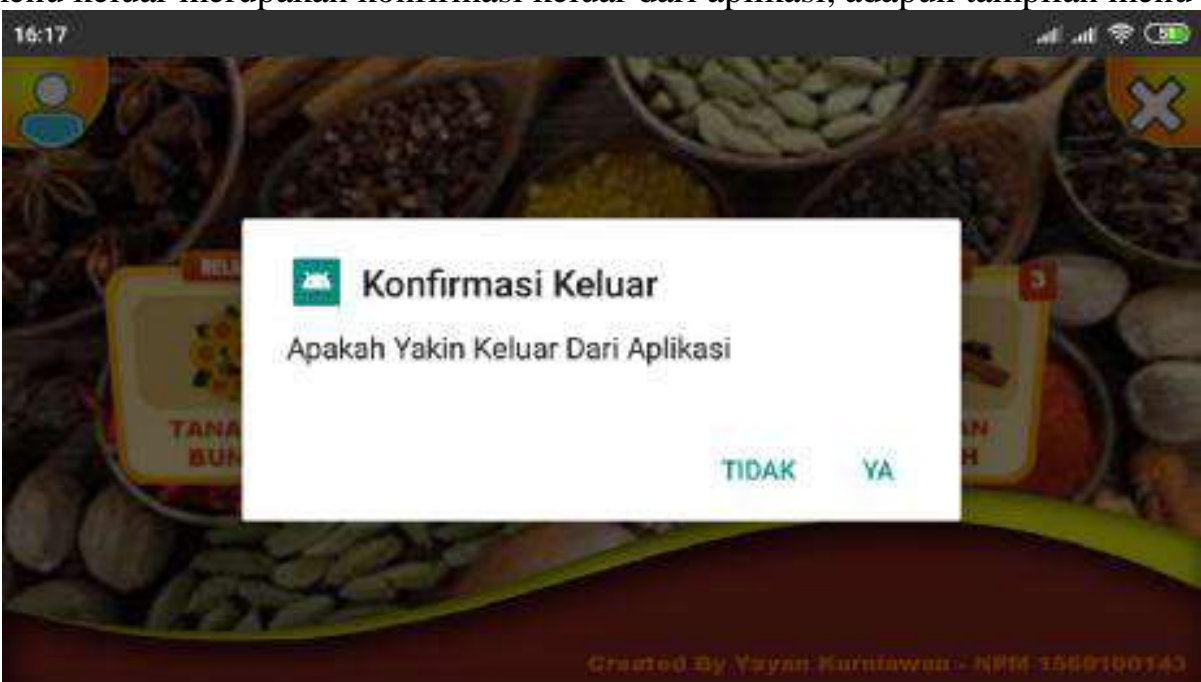

Gambar 6. Menu Keluar 


\subsection{Pembahasaan}

1. Pengujian sistem dilakukan dengan Blackbox Testing. Berikut pengujian black box adalah sebagai berikut :

Tabel 4. Pengujian Black Box

\begin{tabular}{lll}
\hline \multicolumn{1}{c}{ Aktifitas Pengujian } & \multicolumn{1}{c}{ Hasil yang diharapkan } & \multicolumn{1}{c}{ Hasil Pengujian } \\
\hline Menekan Tombol & Sistem akan menampilkan & Sesuai Yang \\
Materi & halaman utama aplikasi & Diharapkan \\
Menekan Tombol & Sistem akan menampilkan & Sesuai Yang \\
Latihan & pilihan materi & Diharapkan \\
Menekan Tombol & Sistem akan menampilkan & Sesuai Yang \\
Latihan & Soal & Diharapkan \\
\hline
\end{tabular}

2. Kuisoner

Kuesioner diberikan kepada 30 responden, hasil pengolahan dari kuisioner dapat dilihat di tabel berikut :

Data hasil yang didapat dari Kuisioner dihitung dengan menggunakan rumus: Rumus $=$ Nilai : Nilai maksimal x $100 \%$ $\mathrm{x} 5$.

Nilai maksimal dilakukan penghitung dengan menggunakan rumus: Nilai maksimal $=$ Responden

Tabel 5. Hasil Kuisoner.

\begin{tabular}{|c|c|c|c|c|c|c|c|c|}
\hline \multirow[b]{2}{*}{ No } & \multirow[b]{2}{*}{ Kriteria } & \multicolumn{7}{|c|}{ Persentase $\%$} \\
\hline & & $\mathrm{SS}(5)$ & $\mathrm{S}(4)$ & $\mathrm{N}(3)$ & $\mathrm{TS}(2)$ & STS(1) & $\begin{array}{l}\text { Total } \\
\text { nilai }\end{array}$ & Persentase \\
\hline 1 & Apakah diperlukan sistem yang baru & 9 & 15 & 4 & 2 & 0 & 121 & $80,66 \%$ \\
\hline 2 & Program bersifat Interaktif dan Dinamis & 10 & 13 & 6 & 1 & 0 & 122 & $81,33 \%$ \\
\hline 3 & $\begin{array}{l}\text { Aplikasi membantu Informasi tanaman obat } \\
\text { berbasis android }\end{array}$ & 7 & 2 & 3 & 0 & 0 & 124 & $82.66 \%$ \\
\hline 4 & $\begin{array}{l}\text { Digunakan sebagai media teknologi informasi } \\
\text { tanaman obat dengan } 3 \text { kategori, yaitu bunga, } \\
\text { buah, dan rempah. }\end{array}$ & 10 & 17 & 2 & 1 & 0 & 126 & $84 \%$ \\
\hline 5 & Warna tampilan menarik & 13 & 6 & 1 & 0 & 0 & 132 & $88 \%$ \\
\hline 6 & Menu tampilan bersifat user friendly & 16 & 3 & 1 & 0 & 0 & 135 & $90 \%$ \\
\hline \multicolumn{8}{|c|}{ Rata-rata Persentase } & $84.44 \%$ \\
\hline
\end{tabular}

Keterangan dari pernyataan : 5 diperoleh dari nilai SS (Sangat Setuju), maka nilai maksimal dari kuisioner ini adalah 30 x $5=150$

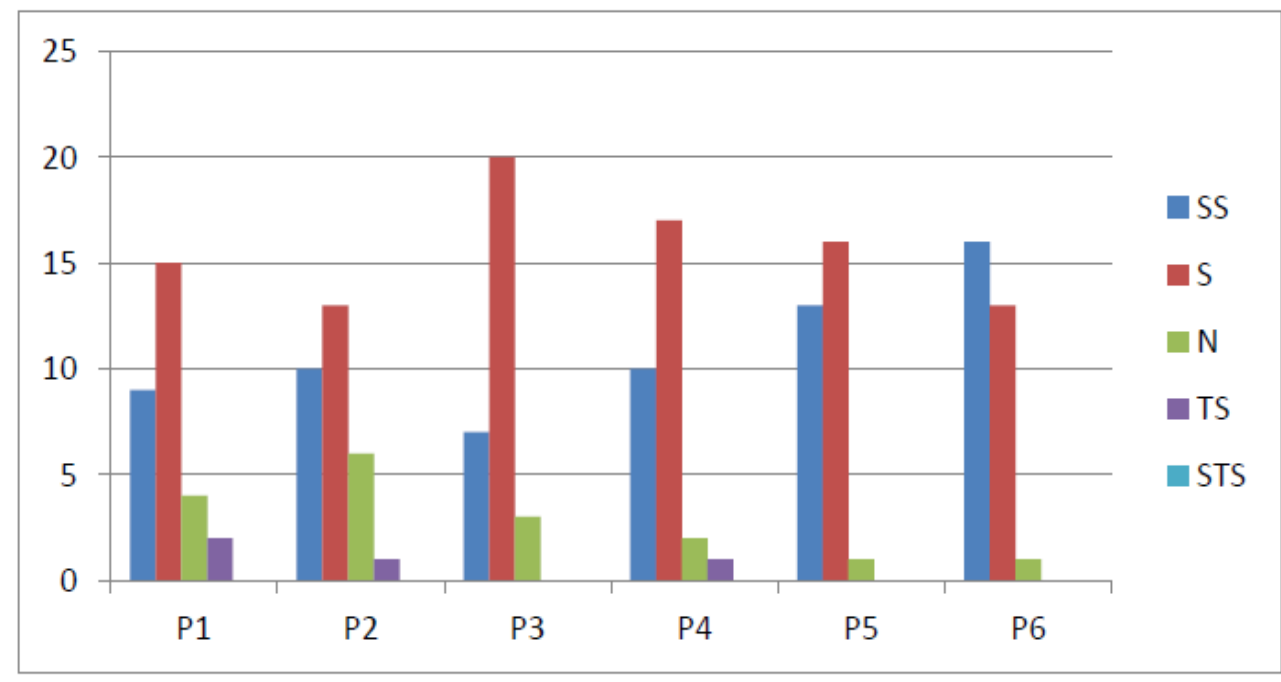

Gambar 7. Grafik Hasil Kuisoner 
Tabel 6. Daftar Pertanyaan

\begin{tabular}{ll}
\hline \multicolumn{1}{c}{ Keterangan Pernyataan } \\
\hline P1 : Apakah diperlukan sistem yang baru & SS : Sangat Setuju \\
P2 : Program bersifat Interaktif dan Dinamis & S : Setuju \\
P3 : Aplikasi membantu Informasi tanaman obat & N : Netral \\
berbasis android & TS : Tidak setuju \\
P4: Digunakan sebagai media teknologi informasi & \\
tanaman obat dengan 3 kategori, yaitu bunga, & \\
buah, dan rempah. & STS : Sangat Tidak Setuju \\
P5 : Warna tampilan menarik & \\
P6 : Menu tampilan bersifat user friendly & \\
\hline
\end{tabular}

Berdasarkan hasil pengujian sistem dengan menggunakan pengujian kuesioner 30 responden umum bahwa aplikasi yang dibangun termasuk kedalam kategori "Sangat Baik" dengan hasil rata-rata 84,44\%. 80,66\% responden menyatakan game ini asik dimainkan. 81,33\% tampilan game menarik. $82,66 \%$ menu dalam game mudah dipahami. $84 \%$ bahasa yang digunakan mudah dipahami. $88 \%$ game ini menambah pengetahuan. $90 \%$ game ini membantu.

\section{Kesimpulan}

Berdasarkan hasil data pengujian: a) Klasfikasi penentuan manfaat tanaman obat herbal dari 31 jenis tanaman herbal yang terdiri dari bunga, buah-buahan dan rempa maka diperoleh Algoritma depth first search yaitu sistem pakar menganalisa atau mendiagnosa gejala-gejala yang dengan melakukan penelusuran kaidah secara mendalam dari simpul akar bergerak menurun ke tingkat dalam yang berurutan di dapat 9 kelompok besar b) Algoritma Depth First earch Pemakaian memori hanya sedikit dan Jika solusi yang dicari berada pada level yang dalam dan paling kiri maka akan menemukannya secara cepat. , Jika ada beberapa solusi yang sama tetapi terletak pada solusi yang berbeda, maka tidak ada kesempatan untuk menemukan solusi yang baik atau pun hanya menemukan satu jalan keluar dari setiap pencariannya sehingga memungkinkan tidak akan ada ditemukannya tujuan yang diinginkan c) Pengujian kuesioner dengan 30 responden bahwa aplikasi yang dibangun termasuk ke dalam kategori "Sangat Baik" dengan hasil rata-rata 84,44.

\section{Referensi}

[1] A. Saleh, "Implementasi Metode Klasifikasi Naïve Bayes Dalam Memprediksi Besarnya Penggunaan Listrik Rumah Tangga," Citec J., vol. 2, no. 3, pp. 207-217, 2015.

[2] K. Hastuti, "Analisis Komparasi Algoritma Klasifikasi Data Mining Untuk Prediksi Mahasiswa non Akfif," Semin. Neurol., vol. 14, no. 1, pp. 241-249, 1994.

[3] L. N. Rani, "Klasifikasi Nasabah Menggunakan Algoritma C4.5 Sebagai Dasar Pemberian Kredit," INOVTEK Polbeng - Seri Inform., vol. 1, no. 2, p. 126, 2016.

[4] C. Darujati and A. B. Gumelar, "Pemanfaatan Teknik Supervised Untuk Klasifikasi Teks Bahasa Indonesia," J. Link, vol. 16, no. February 2012, p. 8, 2016.

[5] R. Suryanto and D. K. Setiawan, "Struktur Data Datawarehouse Tanaman Obat Indonesia Dan Hasil Penelitian Obat Tradisional," in Seminar Nasional Sistem Informasi Indonesia, 2013, pp. 435-440.

[6] S. Sarno, "Pemanfaatan Tanaman Obat (Biofarmaka) Sebagai Produk Unggulan Masyarakat Desa Depok Banjarnegara," Abdimas Unwahas, vol. 4, no. 2, pp. 73-78, 2019.

[7] T. D. W. Winda Rein Nimas Tasia1*, "Potensi Cincau Hitam (Mesona palustris B1.), Daun Pandan (Pandanus amaryllifolius) dan Kayu Manis (Cinnamomum burmannii) Sebagai Bahan baku Minuman Herbal Fungsional.," vol. 19, no. 4, pp. 320-326, 2014.

[8] S. R. Fitriatien, N. E. J. Rachmawati, N. Rahmah, D. A. Safitri, M. R. Pahlevi, and N. M. W. Natsir, "Kegiatan Penanaman Tanaman Obat Keluarga (Toga) Sebagai Salah Satu Usaha Pemberdayaan Siswa SDN Dermo Guna Dalam Menumbuhkan Kepedulian Kesehatan Keluarga," J. Abadimas Adi Buana, vol. 02, no. Vol 1 No 2 (2017), pp. 21-28, 2017.

[9] C. G. Hadi, "Museum Tanaman Herbal Indonesia di Solo," eDimensi Arsit. Petra, vol. II, no. Vol 2, No 1 (2014), pp. 257-261, 2014. 
[10] N. D. Amalina, M. Suzery, B. Cahyono, and N. Bima, "Mengungkap Potensi Metabolit Sekunder Tanaman Herbal Indonesia untuk Menghentikan Metastasis Kanker Payudara: Pendekatan in-silico," Indones. J. Chem. Sci., vol. 9, no. 3, pp. 154-159, 2020.

[11] F. Hidayanto et al., "Tanaman herbal sebagai tanaman hias dan tanaman obat," J. Inov. dan Kewirausahaan, vol. 4, no. 1, pp. 1-4, 2015.

[12] H. D. Hutahaean, "Penerapan Metode Case Based Reasoning Dalam Mengidentifikasi Kerusakan Kamera DSLR,” J. Mantik Penusa, vol. 20, no. 1, pp. 87-90, 2016.

[13] S. W. Nasution, N. A. Hasibuan, and P. Ramadhani, "Sistem Pakar Diagnosa Anoreksia Nervosa Menerapkan Metode Case Based Reasoning," Konf. Nas. Teknol. Inf. dan Komput., vol. I, no. 1, pp. 52-56, 2017.

[14] B. S. Wicaksono, A. Romadhony, and M. D. Sulistiyo, "Analisis dan Implementasi Sistem Pendiagnosis Penyakit Tuberculosis Menggunakan Metode Case-Based Reasoning," in Seminar Nasional Aplikasi Teknologi Informasi (SNATI), 2014, pp. 22-28.

[15] M. Nugraheni, "Rancangan Case-Based Reasoning Menggunakan Sorenson Coeffisient," J. Inform., vol. 6, no. 1, pp. 612-616, 2012.

[16] T. Kandaga and A. Hapendi, "Evaluasi dan Usaha Optimalisasi Algoritma Depth First Search dan Breadth First Search dengan Penerapan pada Aplikasi Rat Race dan Web Peta," J. Inform., vol. 4, no. 1, pp. 39-47, 2008.

[17] T. A. K. NugrohoArif Sudibyo 1, "Pendekatan Algoritma Untuk Mencari Eksentrisitas Suatu Tree dengan Depth First Search," vol. 12, no. April, pp. 9-14, 2017.

[18] R. Bangun and A. Pembelajaran, "Rancang Bangun Aplikasi Pembelajaran Hadis Untuk Perangkat Mobile Berbasis Android," J. Inform., vol. 8, no. 2, pp. 907-920, 2014.

[19] Intan Trivena Maria Daeng, N. . Mewengkang, and E. R. Kalesaran, "Penggunaan Smartphone Dalam Menunjang Aktivitas Perkuliahan Oleh Mahasiswa Fispol Unsrat Manado," e-journal “Acta Diurna," vol. 1, no. 1, pp. 1-15, 2017.

[20] E. Maiyana, "Pemanfaatan Android Dalam Perancangan Aplikasi Kumpulan Doa," J. Sains dan Inform., vol. 4, no. 2, pp. 54-67, 2018. 